Ankara Ecz. Fak. Mec.

5. 183. (1975)
J. Fac. Pharm, Ankara

5. 183. (1975)

\title{
Penisilin - Streptomisin - Eskülin - Striknin - Morfin gibi Farmakolojik Maddelerin Bazı Bitkilere Arpa - Misır Fiğ - fasulye) Etkileri
}

The Effect of Some Pharmacologic Substances (Penicilin Streptomycin - Esculin - Strychnine - Morphnine) on Some Plant (Barley - Corn - Vetch and Kidney bean).

Orhan ALTINKURT * Akgün AYDENIZ** Ferhan HATIPOĞLU** Mehmet AKTAŞ**

$$
\text { GiRis }
$$

Bugüne kadar insan ve hayvan organizmasını veya küçük crshlar olan mikrop organizmasını etkiliyen farmakolojik maddelerin bitkilerdeki etkilerini gösteren bilgiler ve çalışmalar azdır.

İlâç denen teșhis ve tedavi edici aktif etken maddenin; hücreye veya hücrelerin iş bölümü yaparak organizasyonuyla meydana gelen dokulara ve bunların meydana getirdiği canlı organizmalara etkisi olușum ve gelișiminde farklı mıdır?

Bitki organizmasmda, hayvan hücrelerine etkili farmakolojik maddelerin etki benzerliği var mıdır? Canlılık hücre çalıșması olarak kısaca ifade edilebildiğine göre farmakolojik bilinen etkileri canlı bitki hücresinde görmek mümkün müdür? Soruları henüz cevap beklemektedir.

Bilindiği gibi son yıllarda uyartıcı maddeler tarımda geniş çapta uygulanmaktadır. Özellikle gelișmiș ülkelerde, verimi artırmak için bu maddelerden yararlanılmaktadır, Sözgelişi CCC adı verilen Cholin - Chlorid ve Chlorocholin - Chlorid bunlardandir ve Batı Almanya'da çiftçilerin çoğunluğu tarafından kullanılmaktadır (Aydeniz ve Ünver, 1973) ve (Aydeniz ve Dinçer, 1973).

$\mathrm{Bu}$ nedenle, tarimda kullanilmayan fakat insanlar ve hayvanlar üzerinde farmakolojik etkileri bilinen penisilin, streptomisin,

Redaksiyona verildiği tarih: 9, Mayıs. 1975

- Farmakoloji Kürsüsū, Eczacılık Fakūltesi, Ankara Ûniversitesi

* Radyofizyoloji ve Toprak Verimliliği Kürsüsü, Ziraat Fakültesī, Ankara Üniversitesl 
eskülin, striknin, morfin gibi maddelerin bitkiler üzerindeki etkilerinin incelenmesinde yarar görülmüștür.

Araştırmada kullanılan penisilin ve streptomisin antibiyotik. lerden olup, geniş çapta incelenmiştir. Antibiyotiklerin etkisi bakteriostatik veya bakterisitiktir. Bu etki, bakteri bünyesi için gerekli pteroylglutamik acidin veya PABA cidin sentezine mani olarak meydana gelir.

Bilinen bu etkiler yanında bilhassa streptomycin'in Kurarizan etkisinin mevcudiyeti de bilinmektedir (Altınkurt a ve b 1971).

Striknin, Nux vomica (cevzi mukayyi) karga - büken tohumlarında bulunan bir alkaloiddir. $\mathrm{C}_{21} \mathrm{H}_{22} \quad \mathrm{~N}_{2} \mathrm{O}_{2}$ bileşiminde șiddetli bir zehirdir.

Striknin, renksiz, șeffaf kristal, veya beyaz bir tozdur. Kokusuz, çok acı tadda, havada değişmeyen, doymuș çözeltisi alkali karekter gösteren bir maddedir (A.P.A., 1955).

Morfin ise, hașhașdan (Papaver somniferum elde edilen öz veya opios, da denen sakızda \% 5-12 oranında bulunmaktadir. $\left(\mathrm{C}_{17} \mathrm{H}_{19} \mathrm{NO}_{3}\right)_{2} . \mathrm{H}_{2} \mathrm{SO}_{4} .5 \mathrm{H}_{2} \mathrm{O}$ bileșiminde bir alkaloiddir. Insanlar üzerinde analgesik etkiye sahiptir (A.P.A., 1955) .

Canlıların en gelişeni ve en değerlisi olan insan üzerinde açıklanan etkiye sahip bu farmakolojik maddelerin bitki üzerindeki etkilerinin incelenmesi : bu konuda bir ilişkinin saptanması halinde, sonucu çok daha kolay ve zararsız alınabilecek bir yardımcının bulunması olasılığını doğurabileceği gibi: İlerde bitkilere uygulanacak uyartımlarla tarımsal üretimin artırılması da gerçekleşebilir. İlișkinin saptanmaması halinde ise; hayvan ve insan üzerinde bilinen farmakolojik etkilere sahip bu maddelerin aynı canlıların yakın akrabası olan ve aynı yalın birimlerden oluşan bitki organizmalarına etki yapmamalarının nedeni araștırmayı gerektiren bir konudur.

Araștırma bu soruların aydınlığa kavușmasına katkıda bulunmak amacı ile yapılmıștır. 
MATERYAL Ve YÖNTEM

Denemeler 4 grup madde ve 4 bitki türü seçilerek yapılmıștır. Bunlar buğdaygillerden (Gramineae) arpa ve misır ile, baklagillerden (Leguminosae) fiğ ve fasulyedir. hum)

Arpa olarak: İki sıralı beyaz tokak arpası (Hordeum distic-

Misır olarak : Hibrid misır (Zea mays)

Fiğ olarak : Kara fiğ (Vicia villosa)

Fasulye olarak : Adî fasulye (Phaseolus vulgaris) çeşitleri kullanılmıștır.

Farmakolojik maddeler olarak :

I. grup; Penicillin ve Streptomycin gibi antibiyotikler Streptomycin sulfate (IE) $1 \mathrm{gr}$.

Penicillin (IE) Iecillin 200.000 Ü.I. p. G. potasyum, 600.000 Ü.I. p. Procain,

II. grup; Sentetik Kurarizan Eskülin, (Amp. Succinylcholine $\mathrm{HCl} 100 \mathrm{mg}$ ),

III. grup; Santral Sinir Sistemi Stimulanı, Strichnin (amp. 0.001 gr.),

IV. grup; Morphine (amp. Morphine 0.01 gr.).

İșlemler ve dozlar 1 numaralı tabloda görülmektedir.

Tablo I. Araștırmada uygulanan Uyartıcılar ve dozları

\begin{tabular}{|c|c|c|c|c|c|}
\hline Uyartıcı & Ana çözelti & Sulandırılma & $\begin{array}{c}\text { Ana çözeltide } \\
\text { ki miktar }\end{array}$ & $\begin{array}{l}\text { Ana çözelti- } \\
\text { den alınan }\end{array}$ & $\begin{array}{l}\text { Saksıya } \\
\text { uygulanan }\end{array}$ \\
\hline Penisilin-I & $5 \mathrm{ml}$ & - & 800000 Ōnite & $0.1 \mathrm{ml}$ & 16000 Ön. \\
\hline$=\quad-I I$ & " & - & , & $0.3 n$ & 48000 n \\
\hline Streptomisin-I & $5 \mathrm{ml}$ & - & $1000 \mathrm{mg}$ & $0.1 \bowtie$ & $20 \mathrm{mg}$. \\
\hline n $\quad$-II & $"$ & - & , & $0.3 n$ & $60 \%$ \\
\hline Eskülin-I & $2 \mathrm{ml}$ & $10 \mathrm{ml}$ & $100 \mathrm{mg}$ & $0.1 \%$ & 1 \\
\hline -II & , & , & $=$ & 0.3 & 3 \\
\hline Striknin-I & $1 \mathrm{ml}$ & $10 \mathrm{ml}$ & $1 \mathrm{mg}$ & 0.1 & $10 \gamma$ \\
\hline$=-11$ & 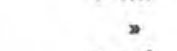 & - & . & $0.3=$ & $30 \gamma$ \\
\hline Morfin-I & $1 \mathrm{ml}$ & $10 \mathrm{ml}$ & $10 \mathrm{mg}$ & 0.1 & $0.1 \mathrm{mg}$. \\
\hline$=-11$ & » & . & $=$ & 0.3 & 0.3 \\
\hline
\end{tabular}


Araștırmada plastik kapaklı $10.5 \mathrm{~cm}$ çapında $5.5 \mathrm{~cm}$ derinliğindeki plastik saksılar kullanılmış; saksıların tabanını kaplayacak oranda özel olarak hazırlanmıș $1 \mathrm{~cm}$ kalınlığındaki poliüretan tohum yataklarının üzerine her saksıya 50 adet arpa, 22 adet mısır, 20 adet fiğ, 10 adet fasulye tohumu ekilmiștir.

Çimlenmeyi sağlamak üzere tohumları yarı yarıa kaplayacak oranda 50 șer ml su katılmıș ve buna adı geçen uyarcıtılar enjektörlerle ilâve edilmiștir.

1 numaralı sekilde arpa tohumlarının çimlenme ve ilk gelişme durumlarina streptomisinin etkisi iki tekerrür olarak görülmektedir.

Görüldügüu gibi tekerrürler arasında iyi bir uyum bulunmaktadir.

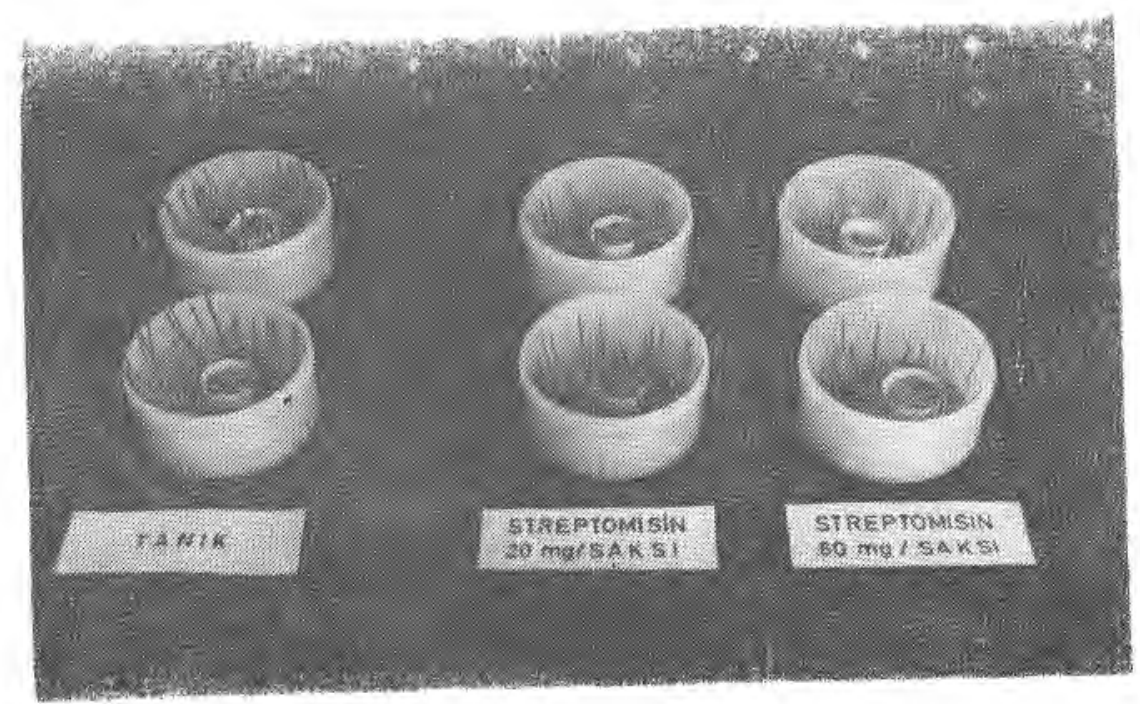

Șek. 1. Bir ișlemin deneme anındaki görünümü.

Tohumlar Radyofizyoloji ve Toprak Verimliliği Kürsüsünün nem ve ısısı kontrollu büyütme odasında çimlenmeye konmuş ve çimlenme ve ilk gelişme dönemindeki etkileri saptamak üzere gerekli ölçümler yapılmıştır. 
Bitkilerin çimlenmeleri üzerinde yukarda yazılan farmakolojik maddelerin etkisi pek belirgin olmamıș ve tanığa oranla çimlenme oranını biraz düșürmüşlerdir. Buna karșın gelișme üzerine, özellikle bitki boyu üzerine etkisi belirgin olmuștur. Araștırmalardan elde edilen sonuçlar ve tartıșma bölümünde sırasıyla arpa - mısır - fiğ fasulyenin çimlenme ve gelişmesine sırasılyla penisilin - stroptomisin - eskülin - striknin ve morfinin etkileri incelenmiștir.

\section{1 - Arpaya Etkiler :}

Arpanın çimlenme ve gelişmesi üzerine farmakolojik maddelerin etkilerine ait araștırma sonuçları 2 numaralı tabloda toplanmıștir.

2 numaralı șekilde ise bütün denemelerde kullanılan substansların arpanın uzunluğuna etkileri grafiklerle gösterilmiș bulunmaktadir.

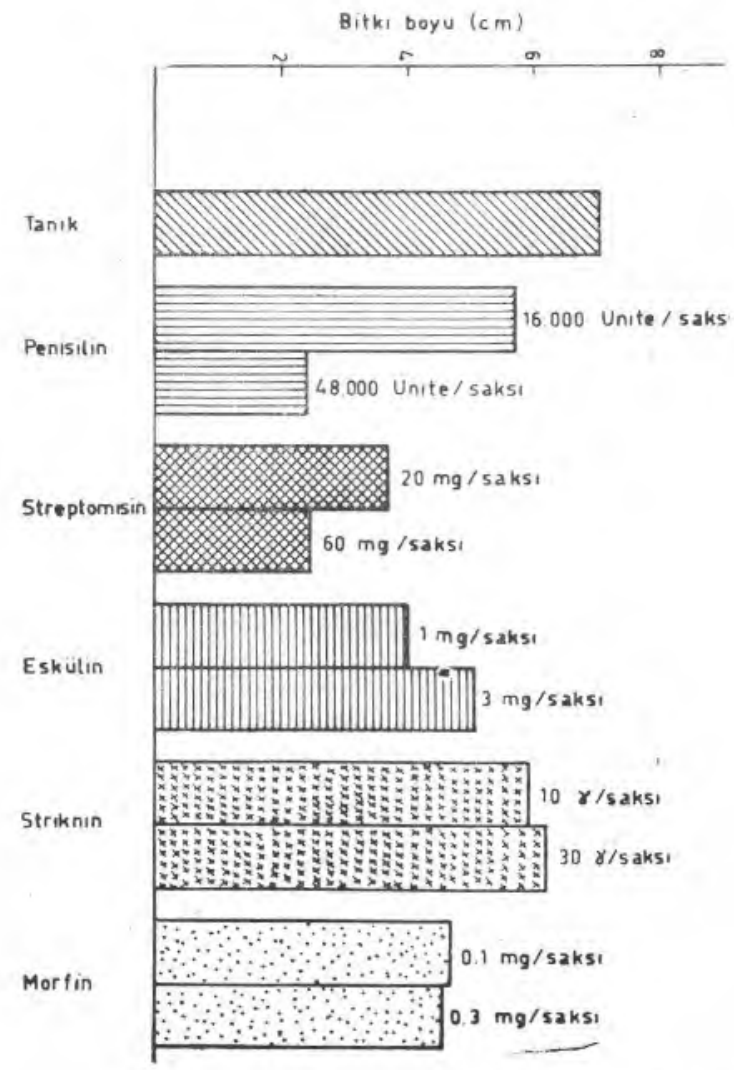

Șek. 2. Uyartıcıların arpanın boyuna etkileri. 
a) Penisilin Etkisi : Penisilin tanığa oranla çimlenmeyi biraz düșürrmüştür (tamı̆ın \% 100'üne karşı \% 93-95 çimlenme). Tekerrürler ortalaması olarak $7.47 \mathrm{~cm}$ 'lik tanı̆ıı bitki boyuna karşın, penisilinin birinci dozu gelișmeyi oldukça artırarak boyu $10.5 \mathrm{~cm}$ ye kadar yükseltmiș, ikinci dozda ise biraz azalarak $8.87 \mathrm{~cm}$ olmuștur. Görüldüügui gibi boy tanıktan yine uzundur.

Kuru madde miktarı ise penisilin dozu arttıkca ortalama 1.346 g'dan ilk dozda 1.411, ikinci dozda 1.877 g'a yükselmiştir.

b) Streptomisinin Etkisi : Streptomisin de çimlenmeyi biraz önlemiștir (Çimlenme oram ortalama \% 94).

Streptomisin'in bitki boyu üzerindeki etkisi olumsuz olmuş ve doz arttıkça bitki boyu șiddetle azalmıștır. Tanığın $7.47 \mathrm{~cm}$ 'lik boyuna karşın ilk dozda boy 4.90'ı ikinci dozda ise $3.28 \mathrm{~cm}$ 'ye gerilemiștir. Görüldüğü gibi ikinci dozda ise boy yarıdan fazla bir düșüş göstermiștir. 3 numaralı șekilde saksılar henüz hasat edilmeden önce gelişmeler arasındaki fark görülmektedir.

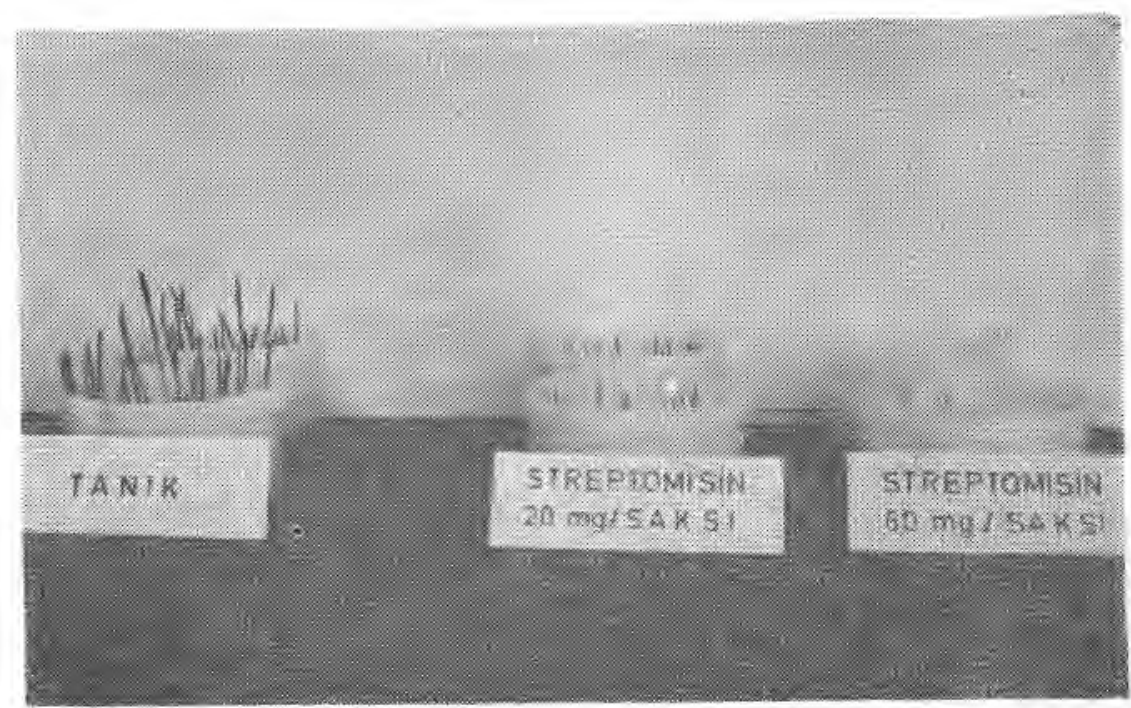

Şek. 3. Streptomisinin çimlenme ve gelișme üzerine etkisi (hasattan önce) 
4 numaralı şekilde ise streptomisinin arpa boyuna etkisi hasattan sonra görülmektedir.

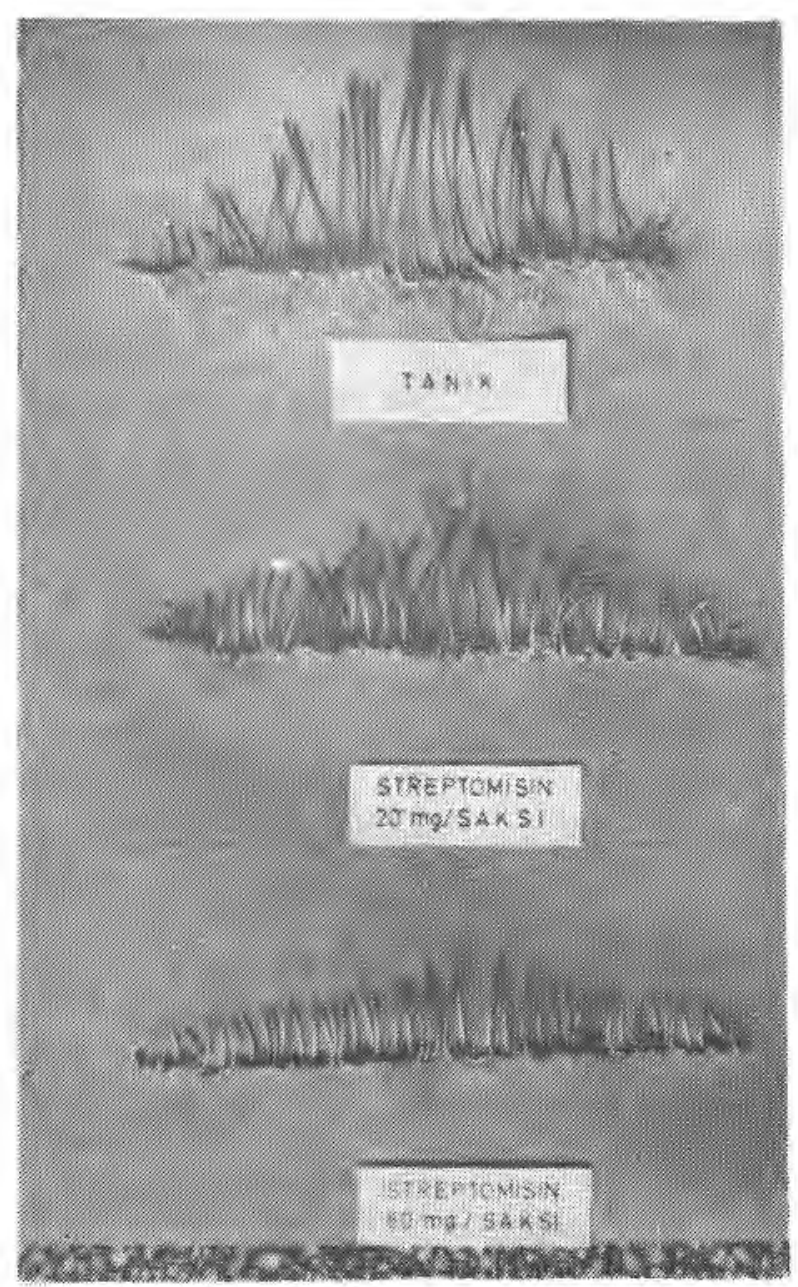

Şek. 4. Streptomisinin arpa boyuna etkisı (hasattan sonra)

Streptomisinin özellikle kök teșekkülünüi önlediği șekil (4) den açık olarak izlenebilmektedir. Gelişme anında streptomisin katılmış saksılarda bir çeşit mantarın gelișmesi özellikle dikkati çekmiștir. 
c) Eskülin'in Etkisi : Çimlenme oranı \% 97-98 dir.

Bitki boyu her iki dozda da bir miktar artmıștır (Tanık 7.47 $\mathrm{cm}$ iken, Eskülin-1 10.54 ve Eskülin-II $10.01 \mathrm{~cm}$ ).

Kuru madde miktarında büyük farklılık görülmemiștir (Tanık $1.346 \mathrm{~g}$, eskülin-I $1.368 \mathrm{~g}$ ve eskülin-II $1.312 \mathrm{~g}$ ).

ç) Striknin'in Etkisi : Striknin arpada çimlenmeyi tanığa oranla \% 1-3 düșürmüștür.

Bitki boyu her iki dozda da tanığın oldukca üzerinde olup 9.79 ve $10.94 \mathrm{~cm}$ 'dir.

Kuru madde miktarı da tanıktan oldukca fazladır (tanık 1.346 g, Striknin-I: $1.459 \mathrm{~g}$, Striknin-II: $1.449 \mathrm{~g}$ ).

d) Morfinin Etkisi : Morfin, arpada çimlenmeyi tanığa oranla \% 1-2 düșürmüștür.

Bitki boyu her iki dozda da tanı̆̆ın üzerinde olarak özellikle birinci dozda $10.74 \mathrm{~cm}$ ile oldukça yüksek boya erişmiştir. İkinci dozda da boy $10 \mathrm{~cm}$ 'in üzerindedir $(10.06 \mathrm{~cm})$.

Kuru madde miktarı ise I. dozda $1.698 \mathrm{~g}$ ile en yüksek değere erişmekte, ikinci dozda biraz azalarak 1.441 g'a düșmektedir.

2 - Misıra farmakolojik susbtanslarin etkileri

Mısırın çimlenmesi ve gelişmesi üzerine farmaklojik maddelerin etkilerine ait araștırma sonuçları 3 numaralı tabloda toplanmiştır.

5 numaralı șekilde ise bütün uyartıcıların mısırın boyuna etkileri grafiklerle gösterilmiş bulunmaktadır. 


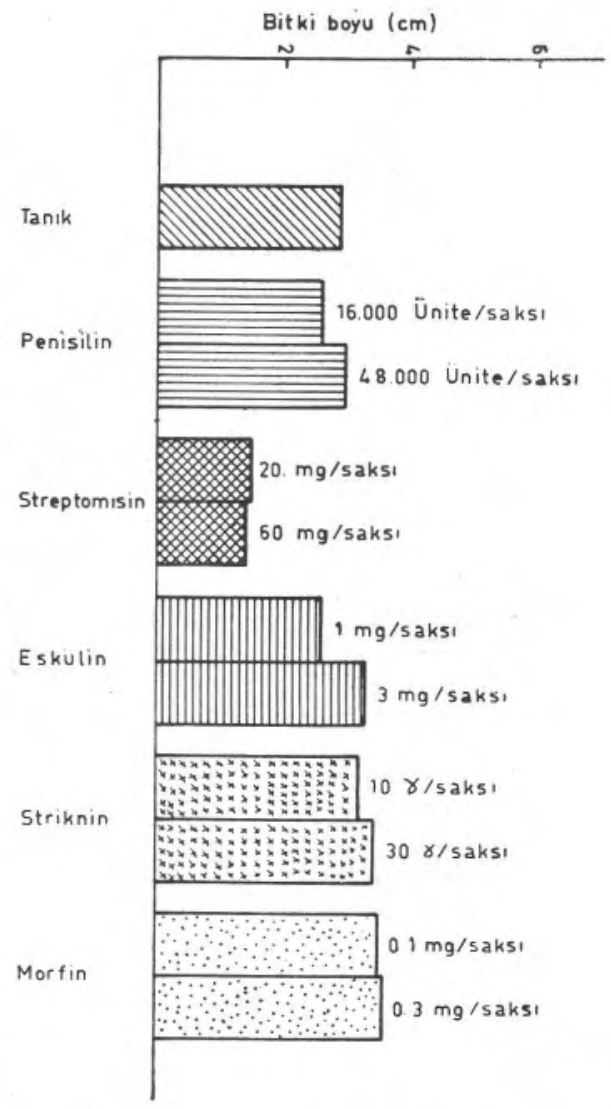

Șek. 5. Uygulanan maddelerin mısırın boyuna etkileri

a) Penilisinin Etkisi : Penisilin tanığa oranla çimlenme oranını, mısırın boyunu ve kuru madde miktarını, çok az oranlarda etkilemiştir.

b) Streptomisinin gelişmeyi geriletici etkisi açık olmuştur. Tanıkta $2.87 \mathrm{~cm}$ olan sürgün boyu yarı yarıya düșerek ilk dozda 1.45, ikinci dozda $1.41 \mathrm{~cm}$ 'ye inmiștir (Șekil 6). 


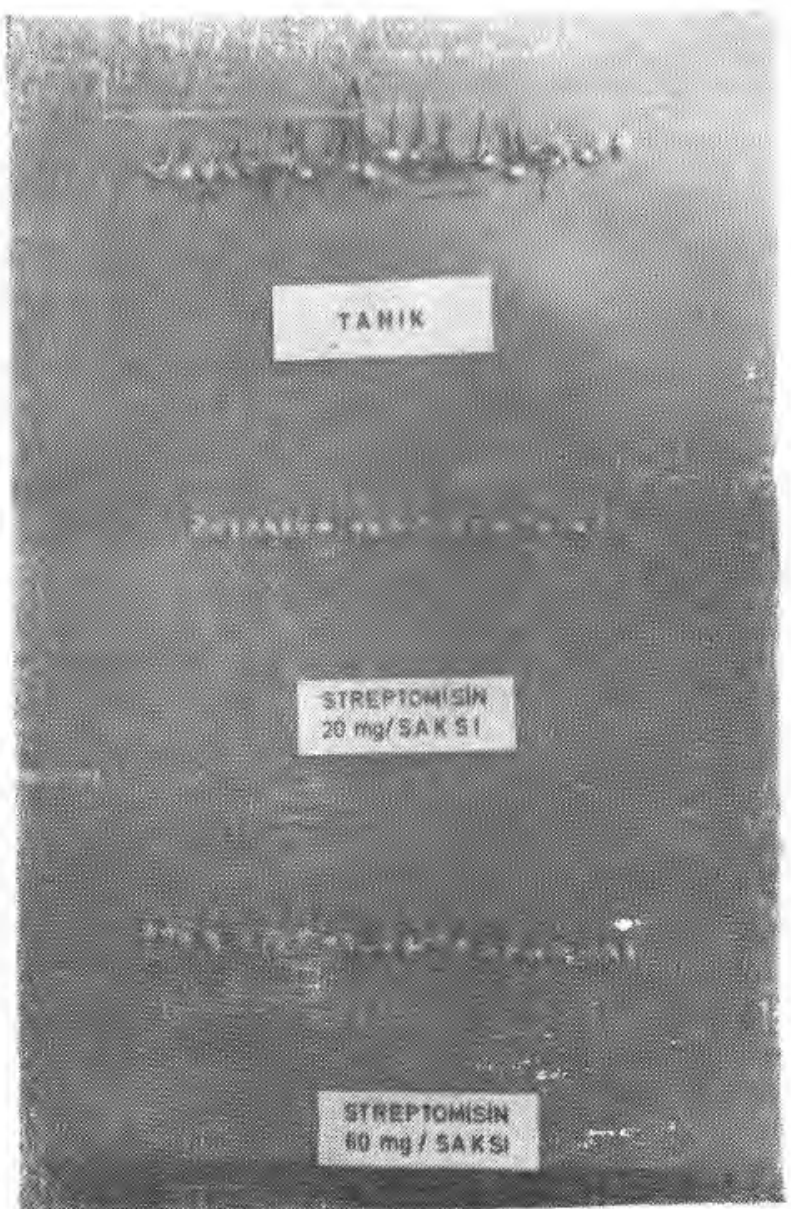

Șek. 6. Streptomisinin mısırın boyuna etkisı.

Streptomisin misırda da kök olușumunu tamamiyle önlemiștir. Streptomisin'in kuru madde üzerindeki etkisi belirgin olmamistur.

c) Eskülin'in Etkisi : Eskülinin birinci dozu mısır boyunu biraz düşürmüș, 2. doz ise biraz yükseltmiștir. Fark belirgin değildir. Kuru maddede büyük bir değișiklik olmamıștır.

c) Strikninin Etkisi : Striknin bitki boyunu artırarak tanıkta $2.87 \mathrm{~cm}$ olan sürgün uzunluğunu birinci dozda 3.16 , ikinci dozda 3.40 cm'ye çıkarmıștır. 
d) Morfinin Etkisi : Morfinin bitki boyunu artırıcı etkisi açık olmuş ve $2.87 \mathrm{~cm}$ lik tanıktaki sürgün birinci dozda 3.47, ikinci dozda $3.58 \mathrm{~cm}$ 'ye yükselmiștir.

\section{3 - Fiğ'e Uygulanan Maddelerin Etkileri}

Fiğ bitkisinin çimlenme ve gelişmesine farmakolojik maddelerin etkileri 4 numaralı tabloda toplanmıștır.

7 numaralı șekilde ise bütün uyartıcıların fiğde bitki boyuna etkisi toplu halde görülmektedir.

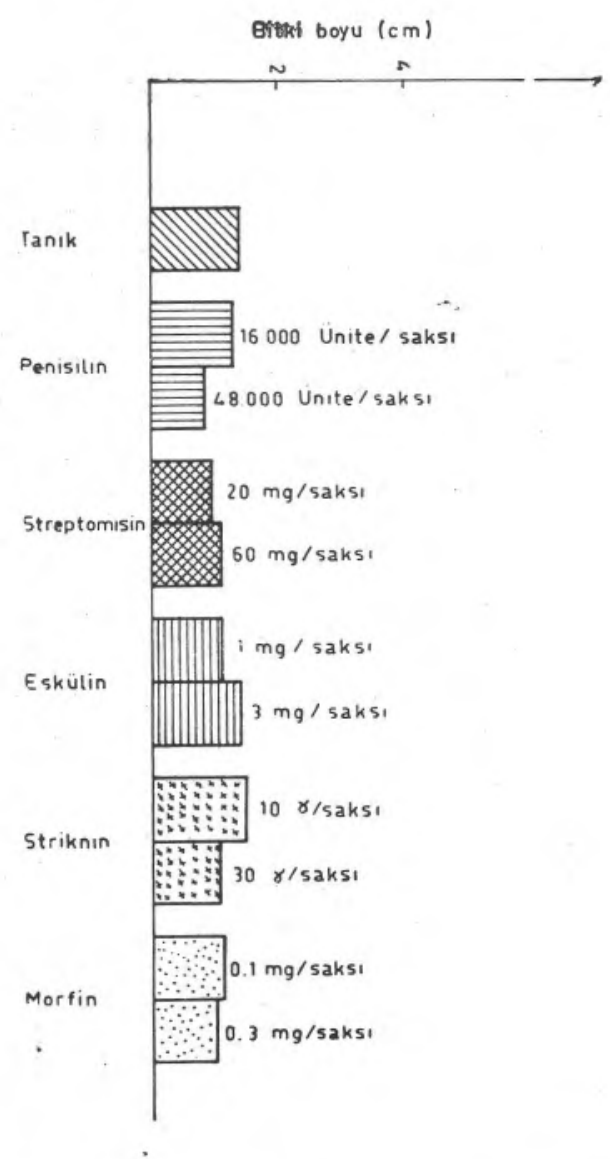

Șek. 7. uyartıcııarın Fiğ bitkisinin boyuna etkileri. 
a) Penisilin'in Etkisi : Penisilin doza bağlı olarak tanığın 1.38 cm'lik bitki boyunu önce 1.28 sonra $0.82 \mathrm{~cm}$ 'ye geriletmiștir.

b) Streptomisinin Etkisi : Streptomisinin sürgün boyu üzerindeki etkisi fiğde belirgin olmuș ve boy 0.98 ve $1.04 \mathrm{~cm}$ 'ye gerilemiștir (Șekil 8.) Şekilde görüldüğü gibi streptomisin fiğde de kök olușumunu yasaklamıștır.

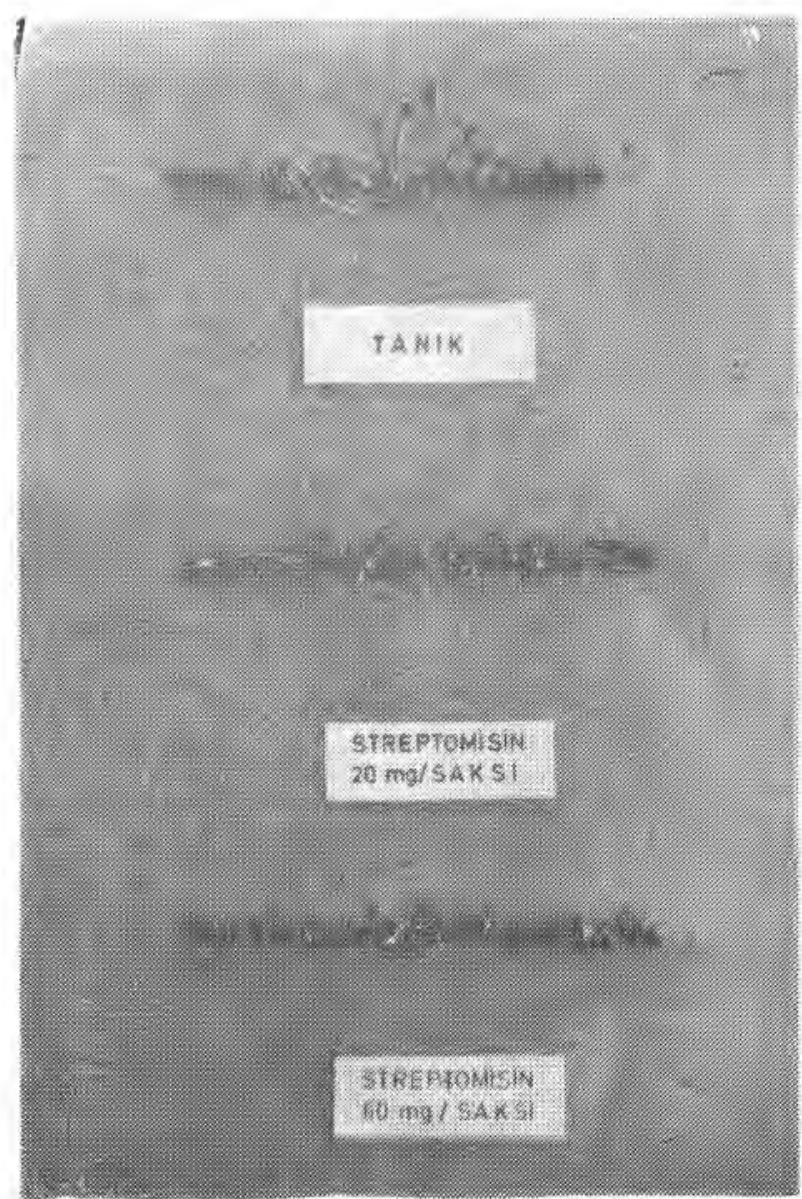

Șek. 8. Streptomisinin fiğ bitkisinin boyuna etkisi 
c) Eskülinin Etkisi : Eskülin özellikle kuru maddeyi azaltıcı bir etki göstermiștir.

ç) Strikninin Etkisi: Strikninin birinci dozu boyu artırıcı, yüksek dozu düșürücü etki yapmıștır.

Striknin aynı zamanda kuru maddeyi de doza bağlı olarak düşürmüş̧ür.

d) Morfinin Etkisi : Morfin doza bağlı olarak tanığın 1.38 cm' lik bitki boyunu önce 1.10 sonra $0.98 \mathrm{~cm}$ 'ye geriletmiştir.

Aynı etki kuru maddede de görülerek 6.515 g'lık ağırlık önce $6.231 \mathrm{~g}$, sonra 5.368 g'a gerilemiștir.

4 - Fasulyeye Uyartıciların Etkileri

Fasulye çimlenme ve gelișmesine uyartıcıların etkileri 5 numaralı tabloda toplanmıștır.

9 numaralı șekilde ise bütün uyartıcıların fasulyede sürgün boyuna etkileri toplu halde görülmektedir.

a) Penisilinin Etkisi : Penisilin doza bağlı olarak tanı̆̆ın 7.06 cm'lik boyunu önce 5.65 sonra $2.38 \mathrm{~cm}$ 'ye geriletmiștir.

Kuru madde üzerine etki belirgin olmamıștır.

b) Streptomisinin Etkisi : Streptomisinin fasulyede de bitki boyunu șiddetle gerileterek önce 3.68 , sonra 2.48 cm'ye düşürmüştür. Ayn zamanda diğer bitkilerde olduğu gibi fasulyede de kök oluşumunu tamamen yasaklamıștır (Șekil 10).

c)Eskülinin Etkisi : Eskülinin birinci dozu fasulyede bitki boyunu oldukça fazla, ikinci doz ise daha az düșürmüștür.

Buna karșın birinci doz kuru madde miktarını artırmış, ikinci doz ise düşürmüștür.

ç) Strikninin Etkisi : Striknin her iki dozda da bitki boyunu biraz düşürmüştür. Strikninin kuru madde üzerindeki etkisi açık olmamıștır. 


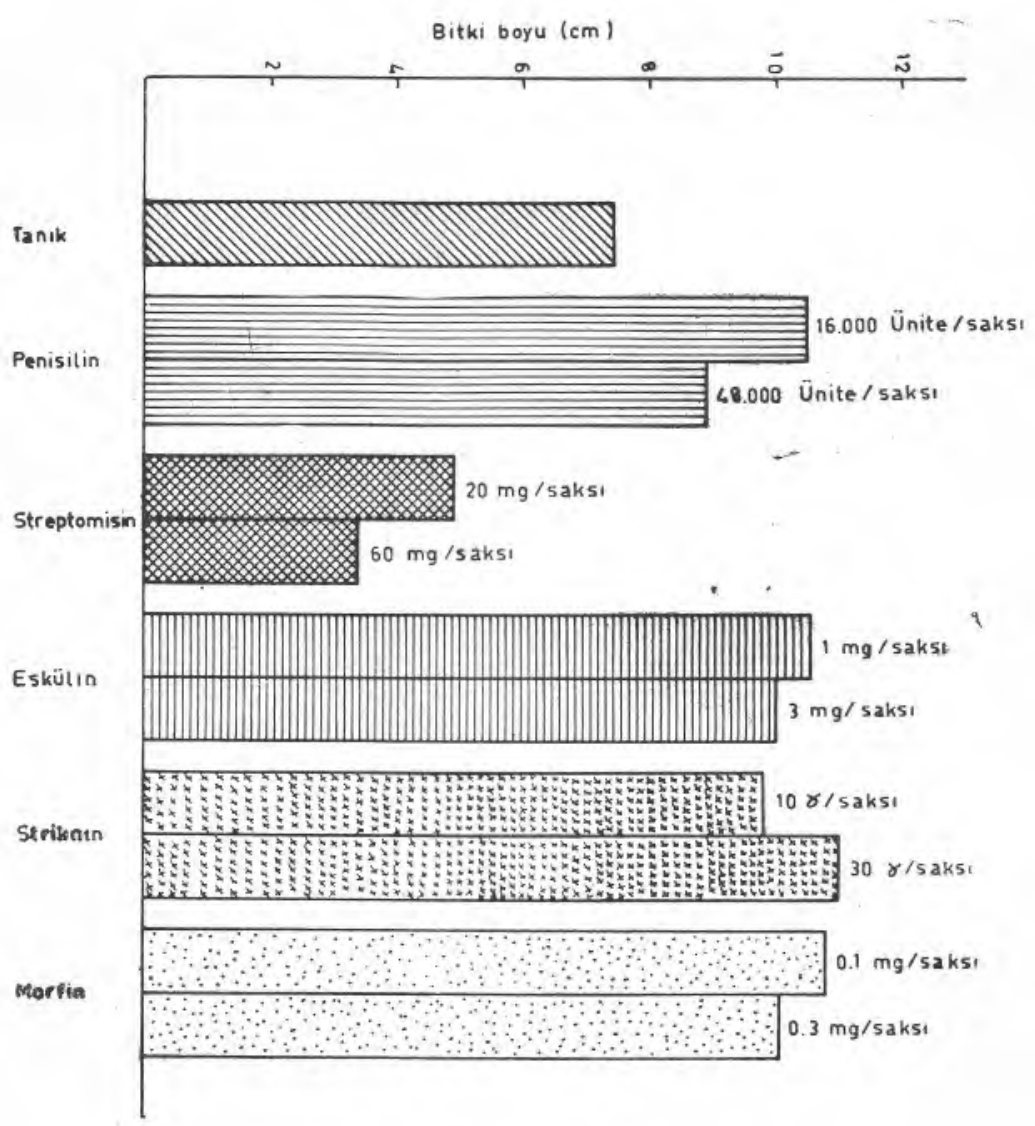

Şek. 9. Uygulanan maddelerin fasulye bitkisinin boyuna etkileri.

\section{Morfinin Etkisi :}

d) Morfin her iki dozda da bitki boyu ve kuru madde miktarunı geriletmiștir.

\section{T A R T I S M A}

Kullanılan farmakolojik substanslardan özellikle streptomisinin boyu üzerindeki etkisi açık olmuş ve araștırmada kullanılan bütün bitki çeşitlerinde boyu cüce bırakmıștır. $\mathrm{Bu}$ etki sonucu bir 


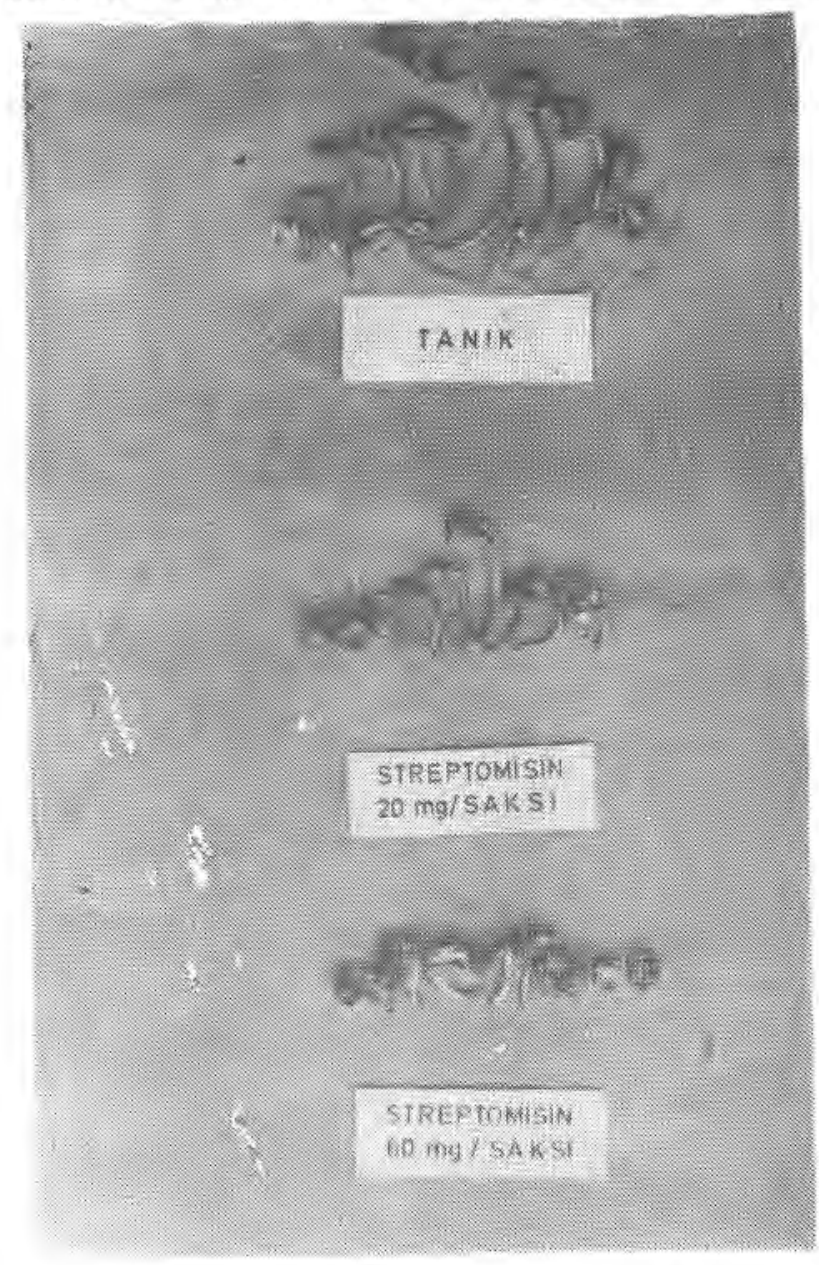

Șek. 10. Fasulye bitkisine streptomisinin etkisi

çok hallerde bitki boyu tanığın yarısı düzeyine dahi erişememiștir. $\mathrm{Bu}$ gelişmeler, Antibiyotiklerin mikrop organizmasındaki protein sentezini sağlayan enzymlere yaptığı ayn etkiyi bitki protein sentezindeki aynı enzimlere benzer etkimesiyle açılanabilir. Belki de antibiyotik dışındaki diğer maddelerin insandaki bilinen etkilerini, bitkide de yine enzim sistemi üzerine hızlandıran veya yavaşlatan bir etkimeye bağlamak mümkün olacaktır. 
Tablo III. - Mısıra Uyartıcıların Etkisi

\begin{tabular}{|c|c|c|c|c|c|c|c|c|c|c|c|c|c|c|c|c|c|c|}
\hline \multirow{3}{*}{\multicolumn{2}{|c|}{ MUAMELELER }} & \multicolumn{5}{|c|}{ ÇIMLENME DUAUMU } & \multicolumn{5}{|c|}{ Sürgün Uzunlukları (cm) } & \multicolumn{7}{|c|}{ KURU MADDE (g) } \\
\hline & & \multicolumn{2}{|c|}{ Çimlenen } & \multicolumn{2}{|c|}{ Çimlenmeyen } & \multirow{2}{*}{\begin{tabular}{|c|} 
Cimlenme \\
orani \\
$\begin{array}{c}\text { ortalama } \\
\%\end{array}$ \\
\end{tabular}} & \multicolumn{2}{|c|}{ Toplam sürgün } & \multicolumn{2}{|c|}{ Ortalama } & \multirow{2}{*}{$\frac{\text { Bitkl }}{\text { boyu }}$} & \multicolumn{2}{|c|}{ Kök + tepe } & \multicolumn{2}{|c|}{ Tohum } & \multicolumn{2}{|c|}{ Toplam } & \multirow[b]{2}{*}{ Ortalama } \\
\hline & & 1 & "I & I & ॥ & & 1 & " & 1 & " & & I & " & 1 & " & 1 & "I & \\
\hline & TANIK & 21 & 20 & 1 & -2 & 93 & 61.0 & 56.8 & 2.50 & 2.84 & 2.87 & 0.615 & 0.596 & 6.345 & 6.382 & 6.960 & 6.978 & 6.969 \\
\hline \multirow{2}{*}{ Penisilin } & 16000 On/saksı & 22 & 22 & - & - & 100 & 59.8 & 54.9 & 2.72 & 2.50 & 2.61 & 0.631 & 0.660 & 6.560 & 6.221 & 7.191 & 6.881 & 7.036 \\
\hline & 48000 Ũn/saksı & 19 & 19 & 3 & 3 & 86 & 51.8 & 59.1 & 2.73 & 3.11 & 2.92 & 0.594 & 0.696 & 6.481 & 5.967 & 7.075 & 6.663 & 6.869 \\
\hline \multirow{2}{*}{ Streptomisin } & $20 \mathrm{mg} / \mathrm{saksi}$ & 19 & 18 & 3 & 4 & 84 & 26.0 & 27.4 & 1.37 & 1.52 & 1.45 & 0.258 & 0.324 & 6.521 & 6.593 & 6.779 & 6.917 & 6.848 \\
\hline & $60 \mathrm{mg} / \mathrm{saks}$ & 22 & 21 & - & 1 & 98 & 29.2 & 31.4 & 1.33 & 1.49 & 1.41 & 0.265 & 0.382 & 6.451 & 6.309 & 6.716 & 6.691 & 6.704 \\
\hline \multirow{2}{*}{ Eskülin } & $1 \mathrm{mg} / \mathrm{saksi}$ & 19 & 22 & 3 & - & 93 & 51.4 & 55.2 & 2.71 & $2.5 i$ & 2.61 & 0.582 & 0.602 & 6.322 & 6.045 & 6.904 & 6.647 & 6.776 \\
\hline & $3 \mathrm{mg} / \mathrm{saks}$ & 20 & $2 i$ & 2 & 1 & 93 & 72.9 & 62.4 & 3.65 & 2.97 & 3.31 & 0.657 & 0.806 & 5.754 & 6.594 & 6.411 & 7.400 & 6.906 \\
\hline \multirow{2}{*}{ Striknin } & $10 \gamma /$ saksı & 17 & 20 & 5 & 2 & 84 & 52.4 & 64.5 & 3.08 & 3.23 & 3.16 & 0.590 & 0692 & 6.254 & 6.740 & 6.844 & 7.432 & 7.138 \\
\hline & $30 \gamma /$ saksı & 21 & 21 & 1 & 1 & 95 & 69.9 & 72.6 & 3.33 & 3.46 & 3.40 & 0.605 & 0.870 & 5.746 & 5.456 & 6.351 & 6.326 & 6.339 \\
\hline \multirow{2}{*}{ Morfin } & $0,1 \mathrm{mg} / \mathrm{saks}$ & 20 & 21 & 2 & 1 & 93 & 71.9 & 70.2 & 3.60 & 3.34 & 3.47 & 0.645 & 0.990 & 6.379 & 5.993 & 7.024 & 6.983 & 7.004 \\
\hline & $0.3 \mathrm{mg} / \mathrm{saksı}$ & 22 & 18 & - & 4 & 91 & 75.4 & 67.3 & 3.43 & 3.74 & 3.58 & 0.679 & 0.904 & 5.438 & 5.708 & 6.117 & 6.612 & 6.365 \\
\hline
\end{tabular}


Tablo IV. - Fiğ'e Uyartıcıların Etkileri 
Tablo V. - Fasulyeye Farmakolojik Substantların Etkileri 
Diğer farmakolojik maddelerin kullanıldığı saksılarda görülmediği halde yalnız streptomisin uygulanmış bütün ișlemlerde bir çeşit mantar oluşmuștur. Bunun streptomisinin bir gurup mikroorganizmayı öldürücü etkisi ile diğer bir gurubun hızla üremesinden ileri gelebileceği düşünülebilir.

Buğdaygillerde streptomisin hariç bütün diğer farmakolojik etkili maddelerin boyu arttırıcı etkileri görüldüğ̈̈ halde; baklagillerde bu etki tersine oluşmuş ve bu maddeler bitki boyunu cüce bırakmiștır.

\section{ÖZET}

Araștırmada buğdaygillerden arpa, mısır ile baklagillerden fiğ ve fasulye bitkilerinin çimlenme ve ilk gelişmelerine penisilin streptomisin - eskülin - striknin - morfinin etkisi incelenmiștir.

Kullamılan farmakolojk substanslardan özellikle streptomisinin bitki boyu üzerindeki etkisi açık olmuş ve gelișme doza bağlı olarak bütün bitkilerde gerilemiștir. Tanığa oranla bitki boyu genellikle ilkel kalarak yarı boya ancak erișebilmiștir.

Streptomisin bütün bitkilerde kök olușumunu yasaklamıștır.

Diğer farmakolojik etkilerde görülmediği halde streptomisin katılmış bütün saksılarda bir çeşit mantar oluşmuştur. Bumun, streptomisinin bir gurup mikroorganizmayı öldürücü etkisi ile mantar üremesinden ileri geldiği düșünülebilir.

\section{S U M M A R Y}

In this research seeds of barley and corp from graminae and Vetch and kidney bean from leguminosae were used and penyciline - streptomycin - esculin - stryhnine and morphine were applied as stimulants.

The effect of streptomycine was clear on all plants varieties and the length of the chasing - retarded in all plants related to the doses of the application.

The streptomycin inhibited rot formation in all varieties.

There were some kind fungaus in all pots of treated with streptomycin but were not in others, it seems that due to the mortal 
effect of streptomycin was on some kinds of microorganisms thus destroying the natural balance with the result that some new organism were increased rapidly.

Interesting results were with other stimulants also but they were not as clear as streptomycin.

\section{I T E R A T Ü R}

1) Altınkurt, O. A. Ü. Ecz. Fak. Mec. 1, 1 (1971).

2) Altınkurt, O. A. Ü. Ecz. Fak. Mec. 1, 4 (1971).

3) American Pharmaceutical Association, The National Formulary 10 th Ed. (1955).

4) Aydeniz, A., Dinçer, D., Ankara șartlarında (Cycocel)'in çeșitli etkenlerle birlikte buğday ürününe etkisi, TUBiTAK, IV. Bilim Kongresi. (1971).

5) Aydeniz, A., Ünver, R., «Cycocel» ve Üșütme'nin çeșitli bitki besin maddesi dozunda buğdaya etkisi, TUBiTAK, IV. Bilim Kongresi. (1973). 